\title{
THE SCOPE OF CODES OF CONDUCT FOR CORPORATE ENVIRONMENTAL RESPONSIBILITY.
}

\author{
DANIEL IGLESIAS MÁRQUEZ \\ PhD researcher at the Tarragona Centre for Environmental Law Studies (CEDAT) \\ Rovira i Virgili University \\ daniel.iglesias@urv.cat
}

Recibido: 24 de septiembre de 2015 / Aceptado: 24 de noviembre de 2015 .

\begin{abstract}
Multinational corporations (MNCs) have emerged as major actors in the global economy and international society is becoming increasingly concerned about their impact on the population and the environment. At present no global regulatory regime is in place to ensure that corporations act in an environmentally responsible manner, especially in host developing countries. All efforts at regulation have been voluntary initiatives from intergovernmental organizations, and, in particular, international and regional codes of conduct that focus on the impact of business in two main areas: social conditions and the environment. These codes are voluntary in nature and have no enforcement mechanism. This note examines the environmental approaches of these instruments. The guiding question is whether environmental provisions included in international codes of conduct fall within international environmental law principles and whether they influence the environmental behavior of MNCs.
\end{abstract}

RESUMEN: Las empresas multinacionales (EMNs) se han convertido en los principales actores de la economía global. Mientras tanto, la sociedad internacional es más consciente de los impactos de las EMNs sobre la población y el medio ambiente. Actualmente, no existe ningún régimen global vigente que asegure un comportamiento

\footnotetext{
- This article is based on research conducted in the context of the Project "Del desarrollo sostenible a la justicia ambiental: Hacia una matriz conceptual para la gobernanza global" (DER2013-44009-P) funded by the Spanish Ministry of Economy and Competitiveness.
} 
ambientalmente responsable de las empresas, especialmente en los países anfitriones. Todos los esfuerzos para regular han recaído en iniciativas voluntarias de organizaciones intergubernamentales, $\mathrm{y}$, particularmente, en códigos de conducta regionales e internacionales enfocados principalmente en el impacto de las empresas en dos áreas: condiciones sociales y medio ambiente. Esta nota examina el enfoque ambiental de estos instrumentos. La pregunta de investigación es si las disposiciones ambientales incluidas en los códigos internacionales de conducta encuadran dentro de los principios del Derecho internacional del medio ambiente y si influyen en la conducta ambiental de las EMNs.

RESUM: Les empreses multinacionals (EMNs) s'han convertit en els principals actors de l'economia global. Mentrestant, la societat internacional es torna més conscient dels impactes de les EMNs sobre la població i el medi ambient. Actualment, no existeix cap règim global vigent que asseguri un comportament ambientalment responsable de les empreses als països amfitrions. Tots els esforços per regular han recaigut en iniciatives voluntàries d'organitzacions intergovernamentals, i, particularment, en codis de conducta regionals i internacionals enfocats principalment en l'impacte de les empreses en dues àrees: condicions socials i medi ambient. Aquesta nota examina l'enfocament ambiental d'aquests instruments. La pregunta de recerca és si les disposicions ambientals incloses en els codis internacionals de conducta enquadren dins dels principis del Dret internacional del medi ambient i si influeixen en la conducta ambiental de les EMNs.

KEY WORDS: Globalization - Multinational Corporations - Codes of Conduct International Environmental Law.

PALABRAS CLAVES: Globalización - Empresas Multinacionales - Códigos de Conducta - Derecho internacional del medio ambiente.

PARAULES CLAUS: Globalització - Empreses Multinacionals — Medi Ambient Codis de Conducta — Dret internacional del medi ambient. 
Summary: I. Introduction. II. Codes of conduct for business. 1. OECD Guidelines for Multinationals Enterprises. 2. Global Compact. 3. UN Norms on the Responsibilities of Transnational Corporations and Other Business Enterprises with Regard to Human Rights. 4. UN Guiding Principles on Business and Human Rights. III. Effectiveness of international codes of conduct concerning environmental protection. IV. Final remarks. V. References.

\section{INTRODUCTION}

Globalization has led to an increase in the number of multinational corporations (hereinafter referred as MNCs) worldwide. According to the United Nations Conference on Trade and Development (UNCTAD), 82,000 parent companies have established 810,000 foreign affiliates all over the world. It is worth noting that 85 per cent of the largest companies are based in the United States, the European Union and Japan. ${ }^{1}$ MNCs have acquired such economic power and political influence that they are in a position to significantly impact the politics, economies and the societies of the countries they operate in. Multinationals have become at least as powerful (economically and politically) as some nations. ${ }^{2}$ They conduct a large number of industrial activities (with a significant environmental impact) in such sectors as extractive industries, energy, water, tourism, shipbuilding, finance and banking.

The displacement of industrial activities towards developing countries as a modus operandi involves several gross human rights violations and the propagation of environmental degradation. MNCs, especially those in the extractive sector, "may adversely affect globally relevant environmental resources, through the production of greenhouse gases, the unsustainable use of biodiversity, and the production of toxic and hazardous substances and waste." ${ }^{\prime 3}$ Numerous cases can be cited in which an MNC has been involved in environmental abuse (e.g. Chevron/Texaco in Ecuador, the Union Carbide plant in Bhopal, Rio Tinto in Bourgainville, Trafigura in Ivory Coast and Shell in Nigeria). ${ }^{4}$ Multinationals, in turn, can have a positive impact on the environment in that they can use their technology and $R \& D$ capability to improve environmental

\footnotetext{
${ }^{1}$ UNCTAD, World Investment Report 2009: Transnational Corporations, Agricultural Production and Development. United Nations Publications, New York-Geneva, 2009, p. 17.

${ }^{2}$ KINLEY, D. and JOSEPH, S., "Multinational Corporations and Human Rights. Questions about their Relationship", Alternative Law Journal, vol. 27, n 1, 2002, pp. 11-7.

${ }^{3}$ MORGERA, E., Corporate Accountability in International Environmental Law, OUP, Oxford, 2009, p. 7.

${ }^{4}$ PIGRAU, A., et al., "Legal Tools for EJOs to Claim Liability for Severe Environmental Harm". EJOLT Report No. 4, 2012. Consulted 5 August 2015, available at: <http://www.ejolt.org/wordpress/wpcontent/uploads/2012/08/120731_EJOLT-4-High.pdf>, pp. 42-48.
} 
conditions. However, their current modus operandi contributes little to reducing their impact on the environment.

Various groups across the social and economic spectrum have expressed their concerns about the environmental degradation being caused by industrial activities, and have demanded greater awareness with regard to business decisions that might have a potential impact on the environment. The performance and behavior of multinationals is therefore relevant to national and international commentators, policy-makers and civil society. Unfortunately, international law does not provide easy solutions to the social and environmental issues posed by multinationals, as it addresses State parties and does not impose obligations directly upon corporations. At the international level, the environmental responsibility of MNCs mainly relies on voluntary and non-binding initiatives, commonly known as corporate social responsibility (CSR), as a tool for selfregulating and self-controlling impact on the environment and the population. ${ }^{5}$ CSR is understood as the voluntary integration of social and environmental concerns into the business operations of a company and the adoption of social and environmental policies by the company's stakeholders.

This trend has led to a proliferation of international codes of conduct by means of which businesses are meant to regulate their behavior by promoting standards of ethical business practices. These codes of conduct attempt to cover different socioenvironmental aspects (social, labor and health conditions, corruption and the environment) in order to promote voluntary ethical business standards and selfregulation. Internationally, a wide range of codes of conduct are currently in effect that differ not only in the stringency and specificity of their requirements, but also in their enforcement mechanisms. ${ }^{6}$

In this note we discuss the environmental provisions, concerns and values of international codes of conduct and their legal scope. The first part analyzes some of the most widely acknowledged international codes of conduct and their references to environmental protection. The second part examines the effectiveness of international codes of conduct concerning environmental protection and their influence on the

\footnotetext{
${ }^{5}$ PERRY-KESSARIS, A., "Corporate Liability for Environmental Harm”, in: Fitzmaurice M., Ong DM., Merkouris P. (eds), Research Handbook on International Environmental Law, Edward Elgar Publishing, Limited Massachusetts, USA, 2010, p. 367.

${ }^{6}$ KOLK, A. and VAN TULDER, R., "Child Labor and Multinational Conduct: A Comparison of International Business and Stakeholder Codes", Journal of Business Ethics, vol. 36, 2002, pp. 291-301.
} 
behavior of corporations. Finally, we conclude that international codes of conduct are weak and ineffective at promoting corporate environmental responsibility.

\section{CODES OF CONDUCT FOR BUSINESS}

In the mid-1980s, "the subject of international environmental law has emerged as a discrete field of public international law."7 The development of this branch of international law is reflected in a large body of principles and rules that have been incorporated into various treaties, binding acts of international organizations, State practices and soft law commitments, all of which are applied bilaterally, regionally and globally. Some principles of international environmental law are embodied or specifically expressed in binding instruments, while others are predominantly based on customary law. The most widely supported and frequently endorsed principles in practice include (i) State sovereignty over natural resources, (ii) responsibility for not causing environmental damage, (iii) the principle of preventive action, (iv) the principle of co-operation, (v) the principle of sustainable development, (vi) the precautionary principle/approach, (vii) the polluter pays principle and (viii) the principle of common but differentiated responsibilities. Some of these principles have their origin in the 1972 United Nations Conference on the Human Environment and the 1992 United Nations Conference on Environment and Development. Both conferences produced declarations of principles regarding environmental protection (known as the Stockholm Declaration and the Rio Declaration), which were adopted by the United Nations General Assembly. Since the adoption of these declarations, further developments in international environmental law have taken place that modify or change the definition, status and scope of the principles and concepts of international environmental law. ${ }^{8}$

Although there are a large number of international environmental protection instruments, they do not apply directly to MNCs because companies lack international legal personality under public international law. De Jonge points out that "the vast bulk of environmentally destructive activities are carried out not by States or international organizations subject to international law, but corporations falling essentially outside of

\footnotetext{
${ }^{7}$ SANDS, PH. and PEEL, J., Principles of International Environmental Law, $3^{\text {rd }}$ ed., CUP, Cambridge, 2012, p. 3 .

${ }^{8}$ KURUKULASURIYA, L. and ROBINSON, NA., Training Manual on International Environmental Law, UNEP, Nairobi, 2006, p. 23.
} 
the coverage of that law." 9 This is a remarkable gap in international law. The absence of international regulation represents an economic and legal advantage for MNCs as they do not have to respond directly for any breaches they might be responsible for. Hence, international environmental law has been unsuccessful in controlling the environmental misconduct and wrongful acts of corporations. However, it has led States to regulate the behavior of corporations within their territory and elsewhere under their jurisdiction in order to prevent harm to the environment.

The above-mentioned issues, inter alia, have raised the debate about the need for internationally regulating and overseeing businesses. Nevertheless, States have been reluctant to impose obligations on corporations in certain areas of international law. ${ }^{10}$ The operations of companies' represent significant interests and benefits for some home States that they may endanger if they were to require MNCs to fulfill higher standards. To date, all of the attempts to establish international obligations for businesses have relied upon voluntary and soft law instruments; intergovernmental (United Nations [UN], the Organization for Economic Co-operation and Development [OECD], the International Labour Organization [ILO] and the World Bank Group [WB]) and multistakeholder initiatives; and international codes of conduct which have emerged from a growing list of human rights abuses attributable to the activities of MNCs.

In the mid-1970s, the UN Commission on Transnational Corporations considered, for the first time, the idea of a code of conduct. ${ }^{11}$ Nevertheless, it was not until the $1990 \mathrm{~s}$ when a proliferation of codes of conduct arose from increased international attention to corporate human rights abuses ${ }^{12}$ and particular emphasis was given to corporate responsibility. ${ }^{13}$ These codes of conduct include the 1976 OECD Guidelines for

\footnotetext{
9 DE JONGE, A., Transnational corporations and international law. Accountability in the global business environment, Edward Elgar, Cheltenham-Northampton, 2011. p. 193.

${ }^{10}$ AUGENSTEIN, D. and KINLEY, D., Beyond the 100 Acre Wood: In which International Human Rights Law Finds New Ways to Tame Global Corporate Power. Sydney Law School Research Paper No. 14/90, 2014. Consulted 29 August 2015, available at: <http://ssrn.com/abstract=2501876>, pp. 4-5.

${ }^{11}$ MÁRQUEZ CARRASCO, C., "El Plan Nacional de España sobre Empresas y Derechos Humanos y la implementación de los pilares Proteger, Respetar y Remediar: oportunidades y desafíos", in: España y la implementación de los Principios Rectores de las Naciones Unidas sobre empresas y derechos humanos: oportunidades y desafios, Huygens, Barcelona, 2014, pp. 25-56.

${ }^{12}$ MONSHIPOURI, M., WELCH, CE. and KENNEDY, ET., "Multinational Corporations and the Ethics of Global Responsibility: Problems and Possibilities", Human Rights Quarterly, n 25, 2003, pp. 965-989.

13 JENKINS, R., "Corporate Codes of Conduct. Self-Regulation in a Global Economy", Technology, Business and Society Programme Paper Number 2, 2001. Consulted 18 August 2015, available at: $<$ http://digitalcommons.ilr.cornell.edu/cgi/viewcontent.cgi?article=1010\&context=codes $>$, pp. 1-33.
} 
Multinational Enterprises, the 1977 Tripartite Declaration of Principles Concerning Multinational Enterprises and Social Policy, the 1982 UN Draft Code on Transnational Corporations, the 1999 Global Compact, the 2003 UN Norms on the Responsibilities of Transnational Corporations and other Business Enterprises with Regard to Human Rights, and the Guiding Principles on Business and Human Rights: Implementing the United Nations 'Protect, Respect and Remedy' Framework adopted by the UN Human Rights Council on $16^{\text {th }}$ June 2011. These instruments are voluntary in nature and differ in the stringency and specificity of their requirements and in their enforcement mechanisms. As a result, the scope of these instruments relies on the ethics and goodwill of each company. However, in June 2014, the UN Human Rights Council adopted a significant resolution to start the process of creating an international legally binding instrument applicable to transnational corporations. The resolution provided for the establishment of an open-ended intergovernmental working group (IGWG) that was mandated with the drafting of an international legally binding instrument to regulate, in international human rights law, the activities of transnational corporations and other business enterprises. ${ }^{14}$ Indeed in the very first session of IGWG, which took place on July 2015 , it became evident that the treaty negotiations would be a long and arduous process. $^{15}$

MNCs have gradually included these international codes of conduct in their day-to-day operations. In this regard, Kolk, Van Tulder and Welters explain that the main reasons that MNCs foster CSR initiatives and environmental protection standards are market pressures combined with legal, economic, political and social influences. ${ }^{16}$ Most codes of conduct refer to sustainable development and incorporate environmental protection standards and mechanisms to encourage more environmentally friendly behavior. The principles and rules of international environmental law can be identified among their

\footnotetext{
${ }^{14}$ UNHRC (e), "Elaboration of an international legally binding instrument on transnational corporations and other business enterprises with respect to human rights. A/HRC/26/L.22", United Nations Human Rights Council, 2006. Consulted 27 August 2014, available at: $<$ http://ap.ohchr.org/documents/alldocs.aspx?doc_id=23480>.

15 Vid. DRAFT - Report of the Open-ended intergovernmental working group on transnational corporations and other business enterprises with respect to human rights. Available at: $<$ http://www.ohchr.org/Documents/HRBodies/HRCouncil/WGTransCorp/Session1/Draftreport.pdf>.

${ }^{16}$ KOLK, A., VAN TULDER, R. and WELTERS, C., "International Codes of Conduct and Corporate Social Responsibility: Can Transnational Corporation Regulate Themselves?" Transnational Corporations, $\mathrm{n}^{\circ}$ 8, 1999, pp. 143-180.
} 
provisions. The sections below explore the environmental concerns and values of some of the most relevant international codes of conduct for business.

\section{OECD Guidelines for Multinational Enterprises}

The OECD Guidelines are recommendations to MNCs operating in and from the territories of the 42 OECD member countries. The Guidelines cover areas such as human rights, the disclosure of information, anti-corruption, taxation, labor relations, environment, competition and consumer protection. Although they directly address businesses, they are merely voluntary recommendations without any binding effect on enterprises, whereas the participating States must commit. In this respect, Ward points out that the Guidelines are "the principal intergovernmentally agreed 'soft law' tool of corporate accountability." 17

With regard to environmental protection, the OECD Guidelines include a chapter on the environment (Section VI) that states that MNCs should "within the framework of laws, regulations and administrative practices in the countries in which they operate, and in consideration of relevant international agreements, principles, objectives, and standards, take due account of the need to protect the environment, public health and safety, and generally to conduct their activities in a manner contributing to the wider goal of sustainable development." ${ }^{\text {"18 }}$ The concept of sustainable development is understood as "development that meets the needs of the present without compromising the ability of future generations to meet their own needs."19 According to Muchlinski, "the approach is based on an accommodation between economic growth, environmental concerns, and the wider social effects of economic activity." 20 This notion has been perversely transferred into the business world through the CSR in order to legitimize the negative impacts of industrial activities.

\footnotetext{
17 WARD, H., "The OECD Guidelines for Multinational Enterprises and Non-adhering Countries Opportunities and Challenges of Engagement", Investment for Development - Forging New Partnerships, 2004. Consulted 26 August 2014, available at: $<$ http://www.oecd.org/investment/investmentfordevelopment/33807204.pdf>, p. 1.

${ }^{18}$ OECD, OECD Guidelines for Multinational Enterprises, OECD Publishing, Paris, 2011, p. 42.

${ }^{19}$ WCED, Our Common Future, OUP, Oxford, 1978, p. 16.

${ }^{20}$ MUCHLINSKI, P., Multinational... op. cit., p. 538.
} 
Section VI on the environment is based on the Rio Declaration and Agenda 21. It also takes into account the 2001 Aarhus Convention on Access to Information, Public Participation in Decision-making, and Access to Justice in Environmental Matters. The section provides general standards of environmental protection and a list of specific tools for corporate environmental accountability, including environmental management systems (EMSs), communication and stakeholder involvement, life-cycle assessment and environmental impact assessment (EIA), risk prevention and mitigation, continuous improvement of corporate environmental performance, education and training of employees, and contribution to public policies. Companies are therefore expected to take into account environmental concerns within their business decision-making processes. This is consistent with Principle 4 of the Rio Declaration ${ }^{21}$ which implies that environmental protection must be an integral part of the development process if development is to be sustainable.

Perhaps the most relevant environmental provision of the OECD Guidelines is the reference to the precautionary principle (Principle 15 of the Rio Declaration), by which MNCs can be prevented from delaying action to prevent or minimize serious environmental damage in the absence of full scientific certainty, as long as such action entails cost-effective measures. Thus, companies are expected to anticipate environmental harm when there is risk or no scientific certainty about the effects of their activities and take measures to avoid harm or choose the least environmentally harmful activity. Hence, this principle requires MNCs to act with care and foresight when making decisions about activities that may have adverse impacts on the environment.

The prevention principle (Principle 21 of the Stockholm Declaration ${ }^{22} /$ Principle 2 of the Rio Declaration ${ }^{23}$ ) is also identifiable in the OECD Guidelines. In international

\footnotetext{
21 Principle 4 of the Rio Declaration states that "[i]n order to achieve sustainable development, environmental protection shall constitute an integral part of the development process and cannot be considered in isolation from it."

${ }^{22}$ Principle 15 of the Stockholm Declaration pronounces that "States have, in accordance with the Charter of the United Nations and the principles of international law, the sovereign right to exploit their own resources pursuant to their own environmental policies, and the responsibility to ensure that activities within their jurisdiction or control do not cause damage to the environment of other States or of areas beyond the limits of national jurisdiction."

${ }^{23}$ Principle 2 of the Rio Declaration asserts that "States have, in accordance with the Charter of the United Nations and the principles of international law, the sovereign right to exploit their own resources pursuant to their own environmental and developmental policies, and the responsibility to ensure that
} 
environmental law, this principle requires States to adopt measures designed to prevent environmental damage. In the OECD Guidelines, the prevention principle is translated into a prevention standard concerning accidents and emergencies that may harm the environment and human health. They suggest that companies should "maintain contingency plans for preventing, mitigating, and controlling serious environmental and health damage from their operations, including accidents and emergencies; and mechanisms for immediate reporting to the competent authorities. ${ }^{24}$ In this regard, prevention is understood to be the minimization of the likelihood that an accident will occur. The prevention principle applied to MNCs consists of three core components: evaluating the likelihood of an accident; being prepared through emergency planning, land-use planning and risk communication; and limiting adverse consequences to health, environment, and property in the event of an accident. It should also oblige MNCs to avoid damaging the environment outside the borders of the country in which they operate and to take special care to ensure that pollution arising from incidents and activities does not spread beyond the borders of the State in which they operate. However, there is no explicit reference to transboundary harm in the OECD Guidelines. The disclosure of environmental information (Principle 10 of the Rio Declaration ${ }^{25}$ ) is also envisaged in the OECD Guidelines. States are under international obligation to provide concerned citizens with appropriate access to information about the environment that is held by public authorities, including information on hazardous materials and activities. According to Partan, the aim of the "duty to inform" is to facilitate the reduction or mitigation of the consequences of environmental risks. ${ }^{26}$ The Guidelines state that companies should "[p]rovide the public and employees with adequate and timely information on the potential environmental, health and safety impacts of the activities of the enterprise, which could include reporting on progress in

activities within their jurisdiction or control do not cause damage to the environment of other States or of areas beyond the limits of national jurisdiction."

${ }^{24}$ OECD, OECD... op. cit., p. 43.

25 Principle 10 of the Rio Declaration states that "[e]nvironmental issues are best handled with the participation of all concerned citizens at the relevant level. At the national level, each individual shall have appropriate access to information concerning the environment that is held by public authorities, including information on hazardous materials and activities in their communities, and the opportunity to participate in decision-making processes."

26 PARTAN, DG., "The 'Duty to Inform' in International Environmental Law", Boston University International Law Journal, num. 6, 1988, pp. 43-88. 
improving environmental performance. ${ }^{27}$ In this regard, the disclosure of environmental information has become common practice among businesses because it builds public confidence and it is the companies themselves that are in the best position to transmit information about their own environmental performance. This might differentiate their activities from those of other companies in the same sector and improve their standing. As a tool for disclosing information, the Guidelines suggest reporting and communication in cases in which scarce or at-risk environmental assets are at stake in regional, national or international contexts. The Guidelines also attempt to ensure the participation of the individuals affected by the environmental, health and safety policies of the companies through adequate and timely communication and consultation. $^{28}$

Finally, the OECD Guidelines provide an implementation mechanism. State members establish National Contact Points (NCPs) to promote the Guidelines and help resolve issues relating to implementation in "specific instances". Through conciliation and mediation, this procedure aims to solve companies' alleged violations of the Guidelines. However, this is still a rather weak mechanism because it is based on cooperation instead of confrontation and emphasizes the protection of the enterprises' interests with regard to confidentiality.

\section{Global Compact}

The Global Compact is regarded as the world's largest corporate citizenship initiative and is intended to promote good corporate practices through a variety of engagement mechanisms, including learning, dialogue and projects. Companies are expected to adopt the principles into their culture, day-to-day operations, and public communications. According to Morgera, "[c]ompanies adhering to the UN Global Compact can arguably be assumed to undertake to comply with certain international principles and may even be assumed to do so in the belief of their binding effect upon them." 29 The Global Compact consists of ten principles in four main fields: human rights, labor, the environment and anti-corruption. Three of the principles focus on the

\footnotetext{
${ }^{27}$ OECD, OECD... op. cit., p. 42.

${ }^{28}$ Ibidem.

${ }^{29}$ MORGERA, E., Corporate... op. cit., p. 79.
} 
environment (Principle 7, Principle 8 and Principle 9). These principles are derived from the Rio Declaration.

Global Compact Principle 7 states that "[b]usinesses should support a precautionary approach to environmental challenges." This principle urges MNCs to avoid environmental damage rather than cure it. It encourages companies to take an active role because it is more cost-effective to take early action to ensure that irreversible environmental damage does not occur. For the precautionary approach to work as intended, companies are expected to assess their environmental impacts and environmental risks, invest in sustainable production methods and research, and develop environmentally-friendly products. In addition, the Global Compact gives advice on how to apply the precautionary approach; for instance, the quality of information can be improved by communicating potential risks for the consumer, the public or the environment. This is closely related to how Principle 10 of the Rio Declaration envisages disclosing environmental information. Transparency and access to information have become key factors in achieving public participation and sustainable development. Both allow the public to know what the company decision-making processes are and what decisions are being contemplated.

Principle 8 of the Global Compact points out that "[b]usiness should undertake initiatives to promote greater environmental responsibility." This principle is based on Agenda 21, Chapter 30 which discusses the role of business and industry in the sustainable development agenda. This Chapter highlights the importance of MNCs in achieving sustainable development and points out that business and industry should increase self-regulation, guided by appropriate codes, charters and initiatives integrated into all elements of business planning and decision-making, and foster openness and dialogue with employees and the public. In order to achieve this, Agenda 21, Chapter 30 suggests two programs. On the one hand, "promoting cleaner production" aims to increase the efficiency of resource use, including the reuse and recycling of waste and the amount of waste discharge per unit of economic output. On the other hand, "promoting responsible entrepreneurship" focuses on the implementation of sustainable development policies. ${ }^{30}$

\footnotetext{
${ }^{30} \mathrm{Vid}$. Agenda 21, available at:

$<\mathrm{https}$ ://sustainabledevelopment.un.org/content/documents/Agenda21.pdf $>$.
} 
Principle 8 of the Global Compact is also closely related to the prevention principle, which emphasizes responsibility for ensuring that activities in your backyard do not cause harm to your neighbors' environment. It describes how businesses are obliged to prevent damage to the environment, and otherwise reduce, limit or control activities that might cause damage or cause a risk of damage. This principle plays a significant role for ecological and economic reasons. On the one hand, some environmental damage is impossible to remedy: for instance, the extinction of a species of fauna or flora, erosion and the dumping of persistent pollutants into the sea. On the other hand, when the damage can be undone, the costs of doing so are often prohibitive. MNCs are obliged to assess their potential harmful activities and to take action at an early stage before damage occurs. Therefore, MNCs should regard preventing environmental damage as a "golden rule", as it can lead to benefits such as improved resource productivity.

Finally, Principle 9 of the Global Compact is also based on Agenda 21, Chapter 34 and is closely related to the prevention principle. This principle indicates that " $[\mathrm{b}]$ usinesses should encourage the development and diffusion of environmentally friendly technologies." The Global Compact encourages companies to use environmentally friendly technology which is less polluting, uses resources in a more sustainable manner, recycles more of their wastes and products, and handles residual wastes in a more acceptable manner. This sort of technology not only contributes to protecting the environment (less waste, fewer residues, lower emissions of environmental contaminants and lower levels of hazardous materials) but also benefits company operations (by reducing operating costs and the use of raw materials, increasing overall competitiveness, and yielding long-term economic benefits). Therefore, MNCs are expected to apply the prevention principle to their activities, at least by adopting effective environmental management practices and technologies.

The Global Compact principles seem to be more ambiguous and have a more limited scope than the OECD Guidelines. As a monitoring and reporting mechanism, companies must submit an annual report ("communication on progress") that describes the progress they have made in implementing the ten principles. If a member of the Global Compact does not submit its "communication on progress" to the Global Compact website for two years in a row, it is no longer allowed to participate in Global Compact events and is labeled "inactive" on the Global Compact website until the submission is made. 


\section{UN Norms on the Responsibilities of Transnational Corporations and Other} Business Enterprises with Regard to Human Rights

In 2003 the UN Norms were approved by the UN Sub-Commission on the Promotion and Protection of Human Rights. At the time, the UN Norms represented an advance in the sphere of international codes of conduct for businesses as they were the result of a formal UN process of consultation that had produced soft law in other fields. The Norms emphasized implementation and enforcement, stating that "States should establish and reinforce the necessary legal and administrative framework for ensuring that the Norms and other relevant national and international laws are implemented by transnational corporations and other business enterprises." 31 The Norms were abandoned in 2005, mainly because of the lack of political endorsement of States. "Most of the States expressed strong reservations, emphasising their determination not to depart from the traditional framework of international law, which stresses the central and pivotal role of the state as a legal subject of public international law.",32

The UN Norms imposed six types of obligations on MNCs: (1) the right to equal opportunity and non-discriminatory treatment; (2) the right to the security of people; (3) the rights of workers, such as no forced or child labor, remuneration that ensures an adequate standard of living, and the possibility of collective bargaining; (4) respect for national sovereignty and human rights; (5) obligations with regard to consumer protection; and (6) obligations with regard to environmental protection.

The Norms made reference to UN treaties and other international instruments related to the environment. MNCs were obliged to respect the standards and principles embodied in these norms. These international treaties and instruments included the Convention on Biological Diversity; the International Convention on Civil Liability for Oil Pollution Damage; the Convention on Civil Liability for Damage Resulting from Activities Dangerous to the Environment; the Declaration on the Right to Development; the Rio

\footnotetext{
31 SUB-COMMISSION ON THE PROMOTION AND PROTECTION OF HUMAN RIGHTS, Commentary on the Norms on the Responsibilities of Transnational Corporations and Other Business Enterprises with Regard to Human Rights. U.N. Doc. E/CN.4/Sub.2/2003/38/Rev.2, 2003. Consulted 26 August 2014, available at: <http://ap.ohchr.org/documents/alldocs.aspx?doc_id=7440>.

${ }^{32}$ MIRETSKI, PP. and BACHMANN, S., "The UN 'Global Business and Human Rights - The UN 'Norms on the Responsibility of Transnational Corporations and Other Business Enterprises with Regard to Human Rights' - A Requiem", Deakin Law Review, vol. 17, nº 1, 2012, pp. 5-41.
} 
Declaration on the Environment and Development; the Implementation Plan of the World Summit on Sustainable Development; and the United Nations Millennium Declaration.

Section $G$ on environmental protection indicated that " $[\mathrm{t}]$ ransnational corporations and other business enterprises shall carry out their activities in accordance with national laws, regulations, administrative practices and policies relating to the preservation of the environment of the countries in which they operate, as well as in accordance with relevant international agreements, principles, objectives, responsibilities and standards with regard to the environment as well as human rights, public health and safety, bioethics and the precautionary principle, and shall generally conduct their activities in a manner contributing to the wider goal of sustainable development."

Like the codes of conduct discussed above, UN Norms Section G paragraph 14 also made explicit reference to the precautionary principle but, unlike the OECD Guidelines and Global Compact, it did not define the way in which this principle applies to companies. Section $\mathrm{G}$ also referred to sustainable development as a wider goal. In order to achieve this goal, MNCs were expected to carry out their activities in accordance with the laws, practices and policies of the country of operation as well as with international agreements, principles and standards regarding environmental perseverance. In addition, MNCs were required to periodically assess the impact of their activities on the environment and human health, and particularly the extent to which they relate to such vulnerable groups as children, the elderly, women and indigenous peoples. In this regard, the assessment had to be distributed in such a way as to be accessible to the United Nations Environmental Programme, the ILO, other interested international bodies, the national government hosting each company, the national government of the country in which the business had its head office and other affected groups. This provision is closely related to the above-mentioned international obligation for the disclosure of environmental information. Finally, the Commentary to Section G made reference to the prevention principle by adopting best management practices and technologies to reduce the risk of MNC activities causing accidents and damage to the environment. 


\section{UN Guiding Principles on Business and Human Rights}

In July 2005, after the UN Norms had been abandoned, Professor John Ruggie was appointed Special Representative to the UN Secretary General (SRSG). ${ }^{33}$ After six years of research and consultations, in 2008, he developed the "Protect, Respect and Remedy Framework" 34 for business and human rights, which outlines the duties and responsibilities for States and MNCs to address business-related human rights abuses. In 2011, the UN Human Rights Council unanimously endorsed the UN Guiding Principles on Business and Human Rights, a set of guidelines that operationalize the UN Framework. ${ }^{35}$ The Guiding Principles rest on three pillars: Protect, Respect and Remedy. The first pillar involves the States' duty to protect against human rights abuses by third parties, including MNCs. The second involves corporate responsibility to respect human rights. Based on this pillar, there is a societal expectation that companies "do no harm" and exercise "due diligence". The third involves access to remedy for victims of human rights abuses.

The Guiding Principles make little reference to the environment, although Professor Ruggie has acknowledged that the environmental harm (pollution, contamination, and degradation) caused by the activities of MNCs generates impacts on a significant number of human rights, including the right to health, the right to life, rights to adequate food and housing, minority rights to culture and the right to benefit from scientific progress. ${ }^{36}$ The environmental-issue gap is filled with other instruments such as those mentioned above. Although recognizing the environment as a substantive right is still

\footnotetext{
${ }^{33}$ UNHRC, "Human rights and transnational corporations and other business enterprises SRSG mandate. E/CN.4/RES/2005/69", United Nations Human Rights Council, 2005. Consulted 27 August 2014, available at: $<$ http://www.ohchr.org/EN/Issues/Business/Pages/ResolutionsDecisions.aspx >.

${ }^{34}$ UNHRC (b), "Report of the Special Representative of the Secretary-General on the issue of Human Rights and Transnational Corporations and Other Business Enterprises: Protect, Respect and Remedy: A Framework for Business and Human Rights. UN Doc A/HRC/8/5", United Nations Human Rights Council, 2008. Consulted 27 August 2014, available at: $<$ http://www.ohchr.org/EN/Issues/TransnationalCorporations/Pages/Reports.aspx>.

${ }^{35}$ UNHRC (d), "Guiding Principles on Business and Human Rights to implement the UN Protect, Respect and Remedy Framework. A/HRC/17/31", United Nations Human Rights Council, 2011. Consulted 27 August 2014, available at: $<$ http://www.ohchr.org/EN/Issues/TransnationalCorporations/Pages/Reports.aspx $>$.

${ }^{36}$ UNHRC (c), "Corporations and human rights: a survey of the scope and patterns of alleged corporaterelated human rights abuse. A/HRC/8/5/Add.2”, United Nations Human Rights Council, 2008. Consulted 27 August 2014, available at: $<$ http://www.ohchr.org/EN/Issues/TransnationalCorporations/Pages/Reports.aspx $>$.
} 
controversial, the human rights directly affected by environmental damage can nevertheless be identified. Under the Guiding Principles, it should be understood that both States and companies must take proactive steps to prevent environmental damage. In this respect, Pigrau and Jaria defended the applicability of the Guiding Principles to activities that can adversely affect the environment. After analyzing several SRSG reports, they concluded that environmental matters fall within the scope of the Guiding Principles. ${ }^{37}$

Although international environmental agreements are not acknowledged in the Guiding Principles, several provisions comparable to the principles and standards of international environmental law can be distinguished. First and foremost, Guiding Principle 17 points out that "[i]n order to identify, prevent, mitigate and account for how they address their adverse human rights impacts, business enterprises should carry out human rights due diligence." 38 This means that companies are obligated to prevent abuses of human rights in which they may be involved either through their own activities or as a result of their business relationships. Moreover, companies are obligated to remedy any abuses that have occurred (Guiding Principle 22). In a broad interpretation of this principle, companies have the obligation to prevent damage to the environment that may be caused by their activities which, in turn, contribute to human rights violations. Therefore, Guiding Principle 22 is related to the environmental principle of prevention. Similarly, the human rights due diligence process includes concepts and approaches that have been developed in the field of the environment, such as impact assessment, stakeholder involvement in decision-making, and life-cycle management. ${ }^{39}$ Guiding Principle 18 states that "business enterprises should identify and assess any actual or potential adverse human rights impacts with which they may be involved either through their own activities or as a result of their business relationships." ${ }^{40}$ The first step in conducting human rights due diligence is to identify

\footnotetext{
${ }^{37}$ PIGRAU A. and JARIA J., "La aplicación de los principios rectores sobre empresas y derechos humanos en el caso de los daños al medio ambiente causados por empresas españolas en terceros países", in: Márquez Carrasco C. (ed.), España y la implementación de los principios rectores de las Naciones Unidas sobre empresas y derechos humanos: oportunidades y desafios, Huygens, Barcelona, 2014, pp. 303-334.

${ }^{38}$ UNHRC (d), "Guiding... op. cit., p. 16.

${ }^{39}$ MORGERA, E., "Final Expert Report. Corporate Responsibility to Respect Human Rights in the Environmental Sphere", University of Edinburgh, 2010. Consulted 26 August 2014, available at: $<$ http://www2.law.ed.ac.uk/euenterpriseslf/documents/files/CSREnvironment.pdf $>$.

${ }^{40}$ UNHRC (d), "Guiding... op. cit., p. 17.
} 
and assess the nature of actual and potential adverse human rights impacts. The Commentary to Guiding Principle 18 points out that the extent of an organization's impact on human rights can be gauged by means of instruments such as environmental impact assessments. After assessing actual and potential impacts, companies are expected to integrate their findings into relevant internal functions and processes, to take appropriate action and to track the effectiveness of their responses. It has been stressed that conducting appropriate human rights due diligence should help business enterprises address the risk of legal claims against them by showing that they took every reasonable step to avoid involvement with an alleged human rights abuse. Finally, broadly speaking, Principle 10 of the Rio Declaration might be included in the provision of Guiding Principle 21, which points out that "[b]usiness enterprises whose operations or operating contexts pose risks of severe human rights impacts should report formally on how they address them." 41 These formal reports are expected to include environmental information that contributes to reducing environmental risk, thus preventing alleged human rights abuses.

Apparently, the Guiding Principles seemed to be a step towards creating an effective instrument to promote best corporate practices. However, they have been criticized for their voluntary nature, which reproduces the same logic applied in the CSR that has been used in recent years.

\section{EFFECTIVENESS OF INTERNATIONAL CODES OF CONDUCT CONCERNING ENVIRONMENTAL PROTECTION}

The adoption of codes of conduct has several potential benefits for MNCs. First and foremost, it creates the public image of a socially and environmentally responsible company. It has been pointed out that codes of conduct are used as a marketing strategy because a growing number of environmentally aware consumers are demanding more environmentally responsible products. Globally, a significant number of consumers buy green (environmentally friendly) products and services ${ }^{42}$ so if MNCs were to fully apply the environmental standards outlined in the codes of conduct, they could cover the

\footnotetext{
${ }^{41}$ Ibid., p. 20.

${ }^{42}$ TINNE, WS., "Green Washing: An Alarming Issue”, ASA University Review, vol. 7, nº 1, 2013, pp. 8188.
} 
highly competitive green market. Worldwide praxis is quite the opposite, however. While in the Global North corporations argue that their products and services are environmentally friendly, in the Global South their operations have a huge impact on natural resources. Moreover, in terms of risk management, the costs incurred by being an environmentally friendly corporation are lower than those incurred by causing ecological damage, which can be extremely high if they impact sales and/or investment or if the corporation is held liable for the damage caused. ${ }^{43}$

In addition, codes of conduct can promote environmentally friendly behavior from at least three perspectives: (i) they can improve the behavior of a company's behavior where that previously may have had few or no standards at all; (ii) they can be used to hold companies publicly accountable if their practices contravene their principles; and (iii) if used inclusively and transparently, they can be used to develop "best practices" and serve as platforms upon which binding regulations can be developed. ${ }^{44}$ However, the effectiveness of these codes relies on MNCs modifying their behavior in order to mitigate the negative impacts of their operations or products on the population and/or the environment. ${ }^{45}$

Most of the doctrine related to the control and responsibility of MNCs acknowledges and agrees that international codes of conduct remain weak and ineffective. This is mainly due to a lack of enforcement and monitoring mechanisms which limit the ability to detect compliance. In this respect, de Jonge points out that "such codes cannot bring about meaningful results unless they establish standards that are measurable, and are supported by effective systems of monitoring and enforcement." 46 Codes of conduct will be most effective when independent bodies are involved in some observing or monitoring capacity. This helps to reach a degree of transparency in relation to corporate behavior. This is particularly evident in their praxis.

\footnotetext{
${ }^{43}$ PERRY-KESSARIS, A., “Corporate... op. cit., p. 369.

44 ABDUL-GAFARU, A., "Are multinational corporations compatible with sustainable development? The experience of developing countries", in: McIntyre, JR., Ivanaj, S., Ivanaj, V. (eds.), Multinational enterprises and the challenge of sustainable development, Edward Elgar, Cheltenham-Northampton, U.K., 2009, p. 61.

45 TAYLOR, G. and CHRISTMANN, P., "Understanding the self-regulation potential of voluntary international initiatives for corporate conduct: the role of sponsor goal”, in: McIntyre, JR., Ivanaj, S., Ivanaj, V. (eds.), Multinational enterprises and the challenge of sustainable development, Edward Elgar, Cheltenham-Northampton, U.K., 2009, p. 207.

${ }^{46}$ DE JONGE, A., Transnational... op. cit., pp. 26-27
} 
Despite adopting these codes, large MNCs continue to have an impact on the environment. Some of the 7,000 companies that participate in the Global Compact (e.g. The Dow Chemical Company, British Petroleum, Unilever, Repsol, DuPont and Royal Dutch Shell) have been accused of large-scale breaches of environmental standards. For example, Repsol Ecuador S.A. joined the Global Compact in 2010 but continues to pollute Yasuni National Park. ${ }^{47}$ Repsol YPF Bolivia S.A., which signed up for the Global Compact in 2006, has been accused of over ten cases of pollution and environmental degradation. ${ }^{48}$ In addition, companies such as Monsanto, Syngenta International $\mathrm{AG}, \mathrm{BASF}$ and DuPont are the major players in agricultural genetic engineering in the private sector. It might be argued that these companies violate Principle 7 of the Global Compact, which is drawn from the Rio Declaration and supports a precautionary approach to environmental challenges.

This situation is also reflected in the several specific instances that have been or are being considered by NCPs and in the complaints relating to OECD Guidelines Chapter VI (Environment). According to the OECD, the number of complaints has increased in the last few years. For example, in August 2008, the Irish and Dutch NPCs were asked to consider an issue related to a gas find off the west coast of Ireland (the "Corrib Gas Project"). Environmental issues related to the project were alleged to violate Chapter VI, paragraphs 2 and 3. Local residents felt that they were not adequately consulted and they had been misled about the safety of the gas pipeline. ${ }^{49}$ In 2002 , Marine Harvest was accused before the Chilean NPC by the NGOs Friends of The Earth (the Netherlands) and Ecoceanos (Chile) of not observing certain environmental and labor recommendations. This case had an important impact on the country and, above all, on the regions where the units were established. It is worth pointing out that most of the specific instances arise from MNC's subsidiaries operating in developing countries.

In sum, although a wide range of principles of international environmental law have been incorporated into corporate codes of conduct, they have nevertheless failed to truly influence the behavior of MNCs.

\footnotetext{
${ }^{47}$ TEMPER, L., et al., "Towards a Post-Oil Civilization. Yasunization and other initiatives to leave fossil fuels in the soil", EJOLT Report No. 6, 2013. Consulted 26 August 2014, available at: $<$ http://www.ejolt.org/wordpress/wp-content/uploads/2013/05/130520_EJOLT6_High2.pdf>.

48 GAVALDÀ, M. and CARRIÓN, J., REPSOL-YPF. Un discurso socialmente irresponsable, Àgora Nord Sud - Observatori del Deute en la Globalització, Barcelona, 2007, pp. 43-45.

49 Vid. OECD (a), Annual Report on the OECD Guidelines for Multinational Enterprises 2011, OECD Publishing, Paris, 2011.
} 


\section{FINAL REMARKS}

The lack of international legally binding instruments designed for corporate environmental responsibility has allowed MNCs to conduct their activities with impunity. Despite the further development of international environmental law, the current international framework does not provide solutions to the environmental impact of multinationals. All existing instruments and mechanisms today are voluntary, including codes of conduct. Empirical evidence has shown that the non-binding nature of these instruments is not sufficient to combat environmental injustices that have important repercussions on humankind, as these companies are still involved in environmental conflicts with grave consequences to the population and the environment, especially in developing countries.

This paper has shown that the environmental provisions of codes of conduct are based on several customary environmental legal principles that have emerged from international conferences and have been adopted by various instruments. Furthermore, the above analysis reveals some of the principles that have received greater attention in relation to the environmental impact of MNCs.

The adoption of codes of conduct benefits corporations because it builds a public image, influences consumer confidence and avoids the creation of instruments that would be legally binding to MNCs. However, the effectiveness of international codes of conduct must be brought into question for a variety of reasons, one of which is that they lack a mechanism for implementation and external monitoring, and that they are often characterized by vague and non-operational standards. In sum, international codes of conduct have little impact on corporate behavior. However, despite their lack of impact and limited scope, codes of conduct can be regarded as the first stepping stones on the road to effective control and the more environmentally responsible behavior of MNCs.

\section{REFERENCES}

ABDUL-GAFARU, A., "Are multinational corporations compatible with sustainable development? The experience of developing countries”, in: McIntyre, JR., Ivanaj, S., Ivanaj, V. (eds.), Multinational enterprises and the challenge of sustainable development, Edward Elgar, Cheltenham-Northampton, U.K., 2009. 
AUGENSTEIN, D. and KINLEY, D., Beyond the 100 Acre Wood: In which International Human Rights Law Finds New Ways to Tame Global Corporate Power. Sydney Law School Research Paper No. 14/90, 2014. Consulted 29 August 2015, available at: $<$ http://ssrn.com/abstract $=2501876>$.

DE JONGE, A., Transnational corporations and international law. Accountability in the global business environment, Edward Elgar, Cheltenham-Northampton, 2011.

GAVALDÀ, M. and CARRIÓN, J., REPSOL-YPF. Un discurso socialmente irresponsible, Àgora Nord Sud - Observatori del Deute en la Globalització, Barcelona, 2007.

JENKINS, R., "Corporate Codes of Conduct. Self-Regulation in a Global Economy", Technology, Business and Society Programme Paper Number 2, 2001. Consulted 18 August 2015 , available

at: $<$ http://digitalcommons.ilr.cornell.edu/cgi/viewcontent.cgi?article=1010\&context=codes $>$.

KINLEY, D. and JOSEPH, S., "Multinational Corporations and Human Rights. Questions about their Relationship", Alternative Law Journal, vol. 27, num. 1, 2002.

KOLK, A., VAN TULDER, R. and WELTERS, C., "International Codes of Conduct and Corporate Social Responsibility: Can Transnational Corporations Regulate Themselves?", Transnational Corporations, nº 8, 1999.

KOLK, A. and VAN TULDER, R., "Child Labor and Multinational Conduct: A Comparison of International Business and Stakeholder Codes", Journal of Business Ethics, vol. 36, 2002.

KURUKULASURIYA, L. and ROBINSON, NA., Training Manual on International Environmental Law, UNEP, Nairobi, 2006.

MÁRQUEZ CARRASCO, C., "El Plan Nacional de España sobre Empresas y Derechos Humanos y la implementación de los pilares Proteger, Respetar y Remediar: oportunidades y desafíos", in: España y la implementación de los Principios Rectores de las Naciones Unidas sobre empresas y derechos humanos: oportunidades y desafios, Huygens, Barcelona, 2014, pp. 25-56.

MIRETSKI, PP. and BACHMANN, S., "The UN 'Global Business and Human Rights The UN 'Norms on the Responsibility of Transnational Corporations and Other 
Business Enterprises with Regard to Human Rights' - A Requiem”, Deakin Law Review, vol. 17, num. 1, 2012.

MONSHIPOURI, M., WELCH, CE. and KENNEDY, ET., "Multinational Corporations and the Ethics of Global Responsibility: Problems and Possibilities", Human Rights Quarterly, nº 25, 2003.

MORGERA, E., Corporate Accountability in International Environmental Law, OUP, Oxford, 2009.

MORGERA, E., "Final Expert Report. Corporate Responsibility to Respect Human Rights in the Environmental Sphere", University of Edinburgh, 2010. Consulted 26 August 2014, available at: $<$ http://www2.law.ed.ac.uk/euenterpriseslf/documents/files/CSREnvironment.pdf $>$.

MUCHLINSKI, P., Multinational Corporations and International Law, OUP, Oxford, 2007.

OECD, OECD Guidelines for Multinational Enterprises, OECD Publishing, Paris, 2011.

OECD (a), Annual Report on the OECD Guidelines for Multinational Enterprises 2011, OECD Publishing, Paris, 2011.

PARTAN, DG., "The 'Duty to Inform' in International Environmental Law", Boston University International Law Journal, $\mathrm{n}^{\circ}$ 6, 1988.

PERRY-KESSARIS, A., “Corporate Liability for Environmental harm”, in: Fitzmaurice M., Ong DM., Merkouris P. (eds), Research Handbook on International Environmental Law, Edward Elgar Publishing, Limited Massachusetts, USA, 2010.

PIGRAU A. and JARIA J., "La aplicación de los principios rectores sobre empresas y derechos humanos en el caso de los daños al medio ambiente causados por empresas españolas en terceros países", in: Márquez Carrasco C. (ed.), España y la implementación de los principios rectores de las Naciones Unidas sobre empresas y derechos humanos: oportunidades y desafios, Huygens, Barcelona, 2014.

SANDS, PH. and PEEL, J., Principles of International Environmental Law, $3^{\text {rd }}$ ed., CUP, Cambridge, 2012. 
SUB-COMMISSION ON THE PROMOTION AND PROTECTION OF HUMAN RIGHTS, Commentary on the Norms on the Responsibilities of Transnational Corporations and Other Business Enterprises with Regard to Human Rights. U.N. Doc. E/CN.4/Sub.2/2003/38/Rev.2, 2003. Consulted 26 August 2014, available at: $<$ http://ap.ohchr.org/documents/alldocs.aspx?doc_id=7440>.

TAYLOR, G. and CHRISTMANN, P., "Understanding the self-regulation potential of voluntary international initiatives for corporate conduct: the role of sponsor goals", in: McIntyre, JR., Ivanaj, S., Ivanaj, V. (eds.), Multinational enterprises and the challenge of sustainable development, Edward Elgar, Cheltenham-Northampton, U.K., 2009.

TEMPER, L., et al., "Towards a Post-Oil Civilization. Yasunization and other initiatives to leave fossil fuels in the soil”, EJOLT Report No. 6, 2013. Consulted 26 August 2014, available at: <http://www.ejolt.org/wordpress/wpcontent/uploads/2013/05/130520_EJOLT6_High2.pdf >.

TINNE, WS., "Green Washing: An Alarming Issue", ASA University Review, vol. 7, $\mathrm{n}^{\mathrm{o}}$ $1,2013$.

UNHRC, "Human rights and transnational corporations and other business enterprises SRSG mandate. E/CN.4/RES/2005/69”, United Nations Human Rights Council, 2005. Consulted 27 August 2014, available at: $<$ http://www.ohchr.org/EN/Issues/Business/Pages/ResolutionsDecisions.aspx $>$.

UNHRC (a), "Interim Report of the Special Representative of the Secretary-General on the issue of Human Rights and Transnational Corporations and other Business Enterprises. UN Doc E/CN.4/2006/97”, United Nations Human Rights Council, 2006. Consulted 27 August 2015, available at: $<$ http://www.ohchr.org/EN/Issues/TransnationalCorporations/Pages/Reports.aspx $>$.

UNHRC (b), "Report of the Special Representative of the Secretary-General on the issue of Human Rights and Transnational Corporations and Other Business Enterprises: Protect, Respect and Remedy: A Framework for Business and Human Rights. UN Doc A/HRC/8/5”, United Nations Human Rights Council, 2008. Consulted 27 August 2014, available at: $<$ http://www.ohchr.org/EN/Issues/TransnationalCorporations/Pages/Reports.aspx $>$.

UNHRC (c), "Corporations and human rights: a survey of the scope and patterns of alleged corporate-related human rights abuse. A/HRC/8/5/Add.2", United Nations 
Human Rights Council, 2008. Consulted 27 August 2014, available at: $<$ http://www.ohchr.org/EN/Issues/TransnationalCorporations/Pages/Reports.aspx $>$.

UNHRC (d), "Guiding Principles on Business and Human Rights to implement the UN Protect, Respect and Remedy Framework. A/HRC/17/31", United Nations Human Rights Council, 2011. Consulted 27 August 2014, available at: $<$ http://www.ohchr.org/EN/Issues/TransnationalCorporations/Pages/Reports.aspx>.

UNHRC (e), "Elaboration of an international legally binding instrument on transnational corporations and other business enterprises with respect to human rights. A/HRC/26/L.22", United Nations Human Rights Council, 2014. Consulted 27 August 2014, available at: <http://ap.ohchr.org/documents/alldocs.aspx?doc_id=23480>.

UNCTAD, World Investment Report 2009: Transnational Corporations, Agricultural Production and Development. United Nations Publications: New York-Geneva, 2009.

WARD, H., "The OECD Guidelines for Multinational Enterprises and Non-adhering Countries Opportunities and Challenges of Engagement”, Investment for Development - Forging New Partnerships, 2004. Consulted 26 August 2014, available at: $<$ http://www.oecd.org/investment/investmentfordevelopment/33807204.pdf $>$.

WCED, Our Common Future, OUP, Oxford, 1978. 